\title{
University Reactor Conversion Lessons Learned Workshop for the University of Florida
}

Eric C. Woolstenhulme

Dana M. Meyer

April 2007

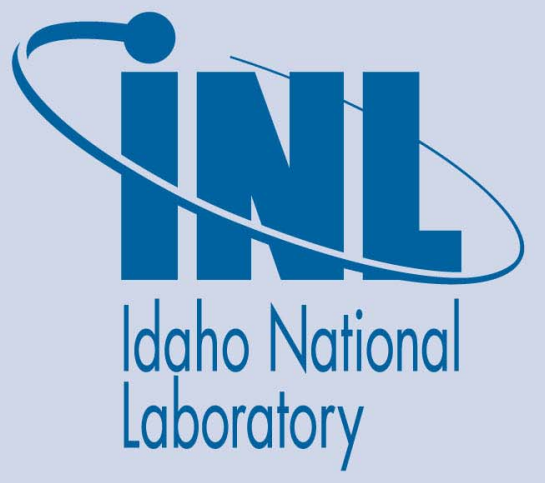

The INL is a U.S. Department of Energy National Laboratory operated by Battelle Energy Alliance 
INL/EXT-07-12603

\title{
University Reactor Conversion Lessons Learned Workshop for the University of Florida
}

\author{
Eric C. Woolstenhulme
}

Dana M. Meyer

April 2007

\section{Idaho National Laboratory \\ Idaho Falls, Idaho 83415}

Prepared for the

U.S. Department of Energy

Office of Nuclear Nonproliferation and Security Affairs

Under DOE Idaho Operations Office

Contract DE-AC07-05ID14517 


\begin{abstract}
The Department of Energy's Idaho National Laboratory, under its programmatic responsibility for managing the University Research Reactor Conversions, has completed the conversion of the reactor at the University of Florida. With this work completed and in anticipation of other impending conversion projects, INL convened and engaged the project participants in a structured discussion to capture the lessons learned. This lessons learned process has allowed us to capture gaps, opportunities, and good practices, drawing from the project team's experiences. These lessons will be used to raise the standard of excellence, effectiveness, and efficiency in all future conversion projects.
\end{abstract}




\section{CONTENTS}

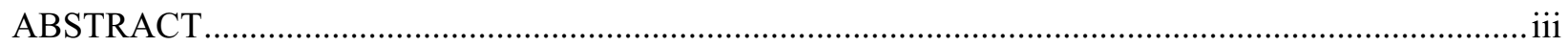

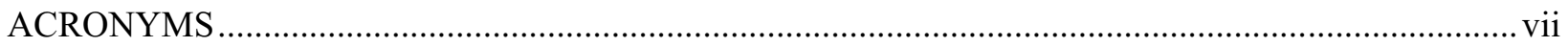

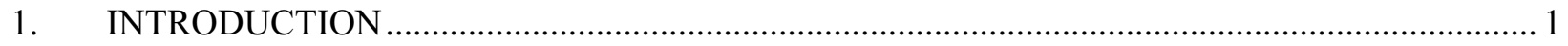

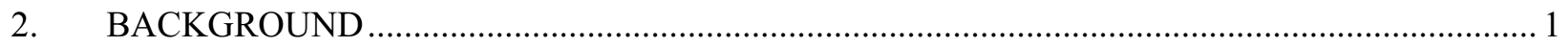

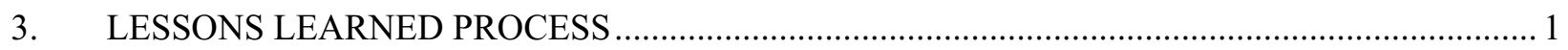

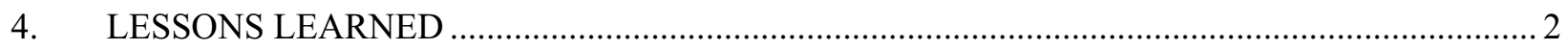

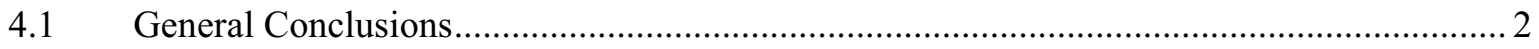

4.2 Lessons Learned Meeting Summary ...................................................................... 3

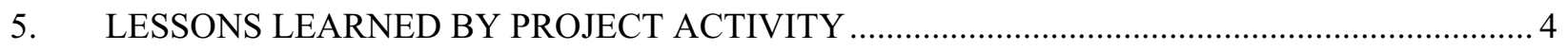

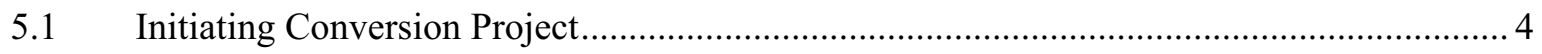

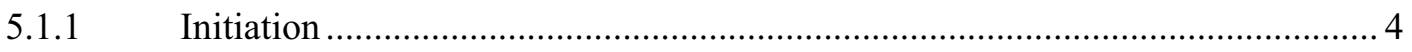

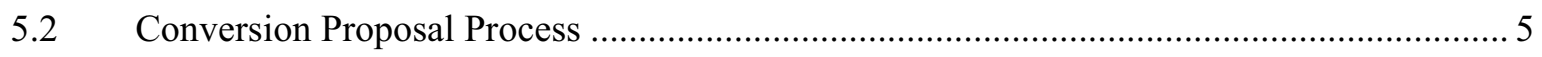

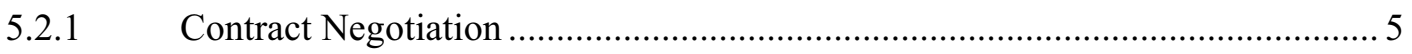

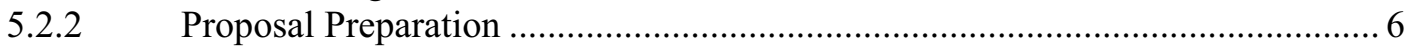

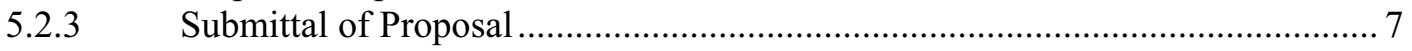

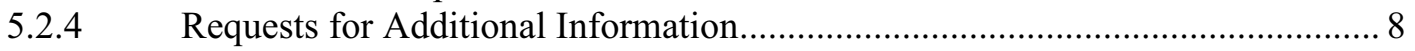

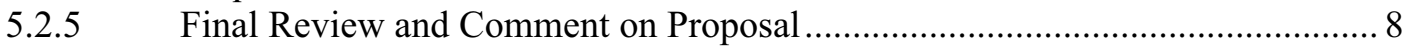

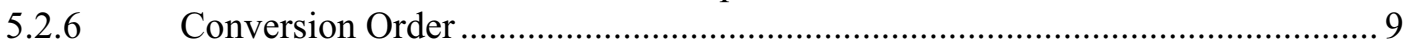

5.3 Fuel and Hardware Development and Procurement...................................................... 9

5.3.1 Fuel Specifications and Drawings............................................................ 9

5.3.2 Fuel Fabrication Statement of Work and Procurement Documents ................... 10

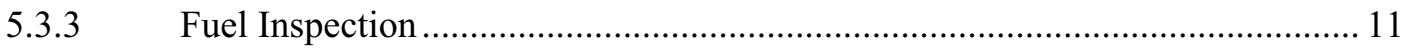

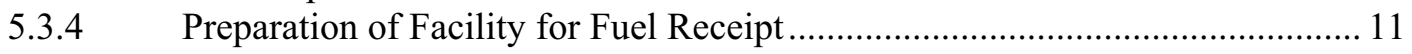

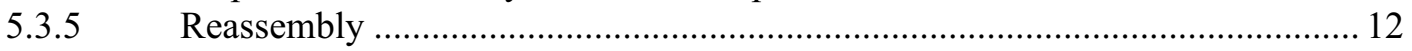

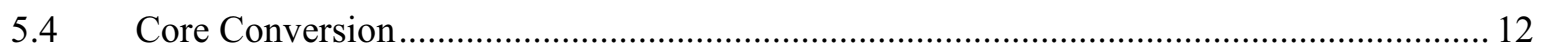

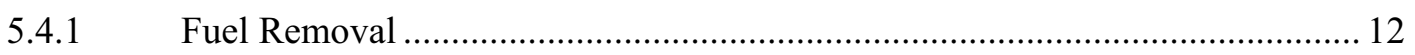

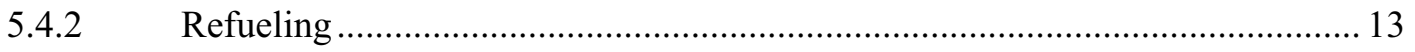




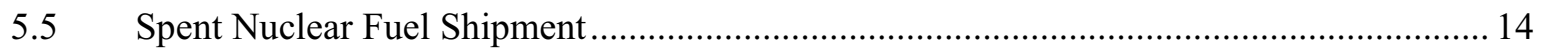

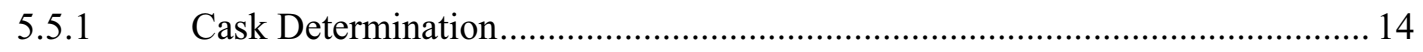

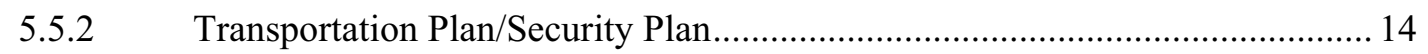

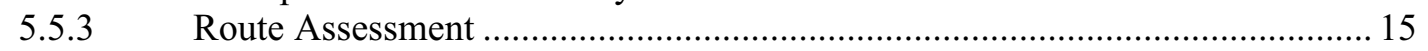

5.5.4 Certification of University Quality Assurance Programs................................ 15

5.5.5 Facility Preparations for Spent Nuclear Fuel Activities................................... 15

5.5.6 Support Equipment/Tools for Spent Nuclear Fuel Activities ........................... 16

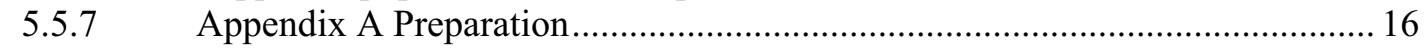

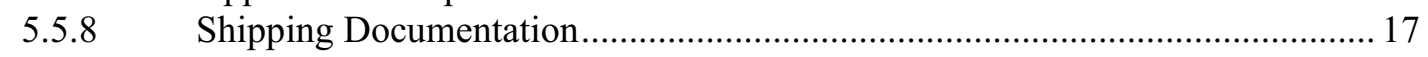

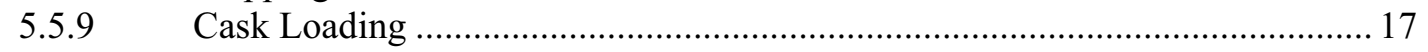

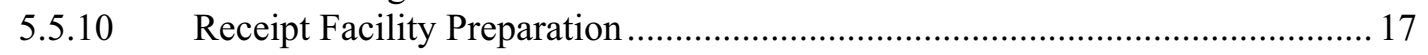

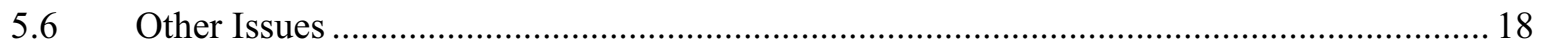

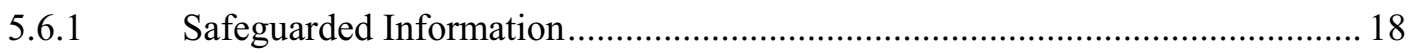

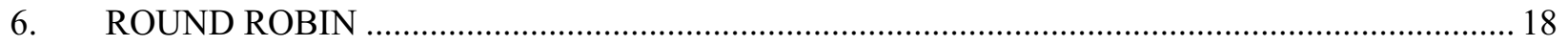

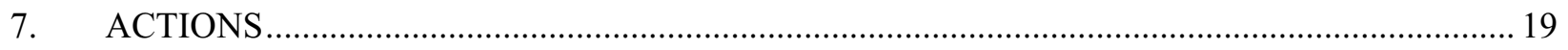

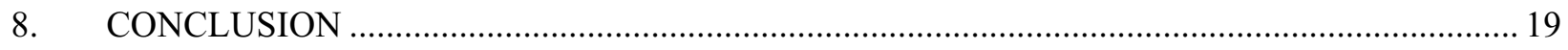




\section{ACRONYMS}

ANL Argonne National Laboratory

DOE U.S. Department of Energy

GA General Atomics

HEU highly enriched uranium

INL Idaho National Laboratory

LEU low-enriched uranium

NNSA National Nuclear Security Administration

NRC Nuclear Regulatory Commission

SNF spent nuclear fuel 


\section{University Reactor Conversion Lessons Learned Workshop for the University of Florida}

\section{INTRODUCTION}

The Department of Energy's (DOE) Idaho National Laboratory (INL), under its programmatic responsibility for managing the University Research Reactor Conversions, has completed the conversion of the reactor at the University of Florida. This project was successfully completed through an integrated and collaborative effort involving INL, Argonne National Laboratory (ANL), DOE (headquarters and the field office), the Nuclear Regulatory Commission (NRC), the universities, and the contractors involved in analyses, fuel design and fabrication, and spent nuclear fuel (SNF) shipping and disposition. With this work completed and in anticipation of other impending conversion projects, INL convened and engaged the project participants in a structured discussion to capture the lessons learned. The objectives of this meeting were to capture the observations, insights, issues, concerns, and ideas of those involved in the reactor conversions so that future efforts can be conducted with greater effectiveness, efficiency, and with fewer challenges.

\section{BACKGROUND}

As part of the Bush administration's effort to reduce the amount of weapons-grade nuclear material worldwide, the National Nuclear Security Administration (NNSA) has established a program to convert research reactors from using highly enriched uranium (HEU) to low-enriched uranium (LEU) fuel.

The research reactor conversion effort is a critical step under the Global Threat Reduction Initiative's Reduced Enrichment for Research and Test Reactors program. As part of this program, NNSA is minimizing the use of HEU in civilian nuclear programs by converting research reactors and radioisotope production processes to the use of LEU fuel and targets. The HEU is weapons-grade nuclear material that can be used to make a nuclear weapon or dirty bomb. The research reactors are secure and are used for peaceful purposes; however, by converting these reactors to use LEU, a significant step is made toward ensuring that weapons-usable nuclear material is secure and safeguarded.

Among the list of research reactors targeted for conversion in 2006 were the University of Florida and Texas A\&M University.

Reactor conversions include analyses, LEU fuel fabrication, reactor defuel and refuel activities, HEU packaging and transportation, and reactor startup.

\section{LESSONS LEARNED PROCESS}

The process for capturing the lessons learned from this project involved taking the schedule of the project activities and focusing feedback and discussion on each respective activity. The feedback and lessons learned discussions were held in an open discussion workshop, including all participating team members and their representatives. To promote a more expedient discussion at the workshops and to help the project team focus on the higher priority areas, a survey was developed and sent to project participants before the workshops. The survey invited those involved in the project to score and offer comments with regard to the projects activities in which they were involved. The survey was formatted with a 5-point Likert scale, where 1 was low or "extremely challenging," and 5 was high or "exceptional." The surveys were collected and scores were entered and averaged for each activity. The average score for each activity is identified in Section 5 of this document. 
Based on survey scores and comments, the workshop agenda was established and timeframes were estimated. Consistent with expectations based on the survey results, the workshop discussions were brief for the unremarkable areas and more extended and detailed in those areas of greatest significance. The detailed lessons learned were captured and the themes and general conclusions were then drawn. The general conclusions and themes tend to apply to all activities (almost as operating principles) and will benefit future project teams and project managers. The more detailed lessons learned align to given activities and apply to the project manager and those involved in the given activity, as that activity is undertaken.

\section{LESSONS LEARNED}

\subsection{General Conclusions}

This project was clearly a success. Nonetheless, there were many detailed lessons learned regarding both technical and project management aspects. The specifics are provided in the following sections; however, some general elements are key to the success of future conversion and spent fuel shipping projects. Future projects will be conducted most effectively, efficiently, and with a minimum of risks, interference, and interruptions if the following are an integral part of the project:

- Project team composition, which includes a project team composed of individuals who are critical thinkers, flexible, and committed to the project results (the following was extracted from the comments submitted: "Having the right people who were willing to buy into the common vision and mission was critical. Everyone had a great personal work ethic. Having a single person who is solely dedicated to the project [allowing that person to stay in contact with all parties involved and to identify and track issues] was instrumental in the success of the project.").

- Communication, including inclusive communications and exchange that provides for effective sharing of needs, expectations, roles, responsibilities, data, assumptions, schedules, and facility and equipment constraints.

- Use of expertise, including confidence in and effective utilization of the varied expertise and experience of the team members.

- $\quad$ Proactivity and individual levels of initiative.

- $\quad$ Early initiation includes the earliest possible initiation of planning and activities at every step in the project process, thereby minimizing the likelihood of time-critical situations.

- Verification and re-verification of data, analyses, specs, assumptions, performance expectations, and equipment fit and function throughout the project.

- Clear and common understanding, including clear expectations of roles, responsibilities, technical variables, and technical results.

- Knowledgeable and informed stakeholders who can advocate for the project, remove barriers, and support decisions and adjustments needed to ensure project success (e.g., public, political, and administrative).

- Compile reactor data includes assembly or compilation of the historical documents that reveal what is known and unknown about the reactor. 
- Value-added government oversight, in which the public interests are served, objectivity is retained, but NRC's experience and expertise is available to the project.

The above list comprised the general themes of the lessons learned meeting. The detailed lessons learned were discussed in the order of project activities, from initiation to closeout, and are provided in the following sections.

\subsection{Lessons Learned Meeting Summary}

The Lessons Learned Workshop for the University of Florida convened on February 22, 2007, at the General Atomics (GA) facilities in San Diego, California. The following were attendees at the workshop:

$\begin{array}{ll}\text { Dana Meyer, INL } & \text { Anthony Veca, GA } \\ \text { Eric Woolstenhulme, INL } & \text { Jason Yi, GA } \\ \text { Doug Morrell, INL } & \text { Ken Mushinski, GA } \\ \text { Dale Luke, INL } & \text { Jim Matos, ANL } \\ \text { Jim Wade, DOE-ID } & \text { Ali Haghighat, UF } \\ \text { Parrish Staples, DOE-NNSA } & \text { Benoit Dionne, UF } \\ \text { Scott Declue, DOE-SRS } & \text { Roy Boyd, STS } \\ \text { Alexander Adams, NRC } & \text { Chip Shaffer, BWXT } \\ \text { Bill Schuser, NRC } & \end{array}$

The following was the agenda for the workshop:

8:00 Welcome and introductory remarks

- $\quad$ Establish ground rules and review agenda

8:30 Discuss and collect lessons learned by each major activity area

- $\quad$ Initiating Conversion Project

- Conversion Proposal Process

10:15 Break

10:30 Discuss and collect lessons learned by each major activity area (continued) 
- $\quad$ Fuel and Hardware Development and Procurement

12:00 Lunch

1:00 Discuss and collect lessons learned by each major activity area (continued)

- Core Conversion

- $\quad$ SNF Shipment

2:20 Break

2:35 Discuss and collect lessons learned by each major activity area (continued)

- $\quad$ Other areas needing to be addressed

3:35 Next steps and assignments

4:10 Closing remarks

4:30 Adjourn

\section{LESSONS LEARNED BY PROJECT ACTIVITY}

The detailed lessons learned were discussed in order of project activities, from initiation to closeout, and are provided in the following sections.

\subsection{Initiating Conversion Project}

\subsubsection{Initiation}

The average survey score was 3.88 .

\begin{tabular}{|c|c|}
\hline Issues & Recommendations \\
\hline $\begin{array}{l}\text { Open communication between the university and } \\
\text { the program went a long way in resolving a } \\
\text { question of roles and responsibilities. In this case, } \\
\text { the program analysts wanted to conduct the } \\
\text { analyses, while the university believed they } \\
\text { should perform them. The university saw it as an } \\
\text { opportunity to thoroughly understand their } \\
\text { reactor. A meeting was held to discuss the } \\
\text { university's desires, rationale, and subsequently } \\
\text { their capabilities and scope of analyses, and it was } \\
\text { agreed to allow the university to do the analyses, } \\
\text { with the program analysts providing guidance and } \\
\text { expertise, as needed. }\end{array}$ & $\begin{array}{l}\text { A valuable lesson learned in this regard was for } \\
\text { the program to understand and respect the } \\
\text { university's objectives, and the related } \\
\text { programmatic benefits, and assist them as needed } \\
\text { to accomplish their goals. } \\
\text { With regard to the question of who would do the } \\
\text { analyses, we needed confidence in each others' } \\
\text { respective capabilities, clarity, and agreement of } \\
\text { roles based on those capabilities, and subsequent } \\
\text { demonstration of those capabilities in the } \\
\text { undertaking of the project. }\end{array}$ \\
\hline
\end{tabular}




\begin{tabular}{|l|l|}
\hline \multicolumn{1}{|c|}{ Issues } & \multicolumn{1}{|c|}{ Recommendations } \\
\hline $\begin{array}{l}\text { The university team was segregated a bit and it } \\
\text { being shared appropriately. }\end{array}$ & $\begin{array}{l}\text { A kick-off meeting with the university, designer, } \\
\text { fabricator, analyst, shipping support, and shipper } \\
\text { should take place as soon as possible to facilitate } \\
\text { formal and systematic documentation of ALL } \\
\text { technical and functional requirements for the } \\
\text { entire project in a technical and functional } \\
\text { requirements document. This would clarify roles, } \\
\text { expectations, and requirements, and especially } \\
\text { ensure that each piece of the design/specification } \\
\text { could be verified against those requirements. } \\
\text { Technical and functional requirements documents } \\
\text { would be signed and become the "binding" } \\
\text { document that everyone must abide by. Doing this } \\
\text { will help eliminate many of the design problems } \\
\text { that were experienced on this project. It would be } \\
\text { a living document that gets revisited at each } \\
\text { review. }\end{array}$ \\
\hline $\begin{array}{l}\text { Insufficient coordination of reviews caused delays } \\
\text { and confusion. }\end{array}$ & $\begin{array}{l}\text { Explicitly discuss "who else" needs to be "on } \\
\text { board" to determine the support needed and } \\
\text { establish essential contacts for review and } \\
\text { information. }\end{array}$ \\
$\begin{array}{l}\text { Direct the university to provide, at the preliminary } \\
\text { meetings, a list of those individuals that they want } \\
\text { to review drawings, specs, and such. }\end{array}$ \\
\hline
\end{tabular}

\subsection{Conversion Proposal Process}

\subsubsection{Contract Negotiation}

The average survey score was 3.0.

\begin{tabular}{|l|l|}
\hline \multicolumn{1}{|c|}{ Issues } & \multicolumn{1}{|c|}{ Recommendations } \\
\hline $\begin{array}{l}\text { Delays were experienced in the contracting } \\
\text { process due, in large part, to lack of understanding } \\
\text { of the work and time constraints by the contracts } \\
\text { representatives. }\end{array}$ & $\begin{array}{l}\text { Involve contracts/procurement people early in the } \\
\text { process to promote an understanding of the work } \\
\text { that mitigates nonessential delays. }\end{array}$ \\
\hline $\begin{array}{l}\text { Procurement and contracts personnel play a } \\
\text { pivotal role in managing risks and clarifying } \\
\text { obligations through the contracting process. } \\
\begin{array}{l}\text { However, their effectiveness can be suboptimized } \\
\text { if they are ill-informed and are not involved early. }\end{array}\end{array}$ & $\begin{array}{l}\text { Start negotiations early to ensure the procurement } \\
\text { process is less troublesome. Involve procurement } \\
\text { personnel from both parties early, so that all } \\
\text { parties are informed and working together. }\end{array}$ \\
\hline
\end{tabular}




\subsubsection{Proposal Preparation}

The average survey score was 2.83 .

\begin{tabular}{|c|c|}
\hline Issues & Recommendations \\
\hline $\begin{array}{l}\text { The age and history of any given reactor } \\
\text { potentially allows for the likelihood that changes } \\
\text { have occurred in designs, equipment, } \\
\text { functionality, and such. These changes impact the } \\
\text { design, analysis, and any number of activities on } \\
\text { these projects. }\end{array}$ & $\begin{array}{l}\text { Advise university early (at the start of the process } \\
\text { or at the initial phase of the analysis) to recover } \\
\text { and provide any historical documents, geometries, } \\
\text { specifications, and such that are available. They } \\
\text { also need to identify what information is missing } \\
\text { so they can conduct whatever activities are } \\
\text { necessary to fill those data gaps. }\end{array}$ \\
\hline $\begin{array}{l}\text { Lots of time was spent up front trying to } \\
\text { determine format, content, and such. A clearer } \\
\text { guideline of what the format (and some } \\
\text { boilerplate) would be extremely helpful in } \\
\text { preparing the proposal. }\end{array}$ & $\begin{array}{l}\text { Now that it has been published, we need to use the } \\
\text { NRC guide/template when preparing the proposal. }\end{array}$ \\
\hline $\begin{array}{l}\text { Although proposals are not due until a specific } \\
\text { date, involvement of NRC to conduct upfront } \\
\text { negotiations and clarify expectations and } \\
\text { contractual obligations DURING proposal } \\
\text { development would greatly improve the process. }\end{array}$ & $\begin{array}{l}\text { Involve NRC in the proposal process as soon as } \\
\text { reasonable regarding those areas where NRC } \\
\text { involvement is stipulated (i.e., before the postal } \\
\text { worker drops it off). }\end{array}$ \\
\hline $\begin{array}{l}\text { Proposal preparation went well. Lots of } \\
\text { interaction back and forth with a clear, } \\
\text { comprehensive plan and identification of who was } \\
\text { responsible for what. }\end{array}$ & $\begin{array}{l}\text { Embrace a collaborative and interactive operating } \\
\text { philosophy, yielding constructive and clear } \\
\text { communication and exchange. }\end{array}$ \\
\hline $\begin{array}{l}\text { The NRC oversight was value-added yet remained } \\
\text { objective. Several aspects of the proposal can only } \\
\text { be decided by NRC; therefore, early, open } \\
\text { involvement is crucial. Use NRC as a technical } \\
\text { resource/sanity check, and not just for answering } \\
\text { administrative-type questions (e.g., changes to } \\
\text { technical specifications), puts NRC in a position } \\
\text { to "advocate" the conversion proposal on behalf } \\
\text { of the university. Anytime the proposal preparer } \\
\text { questions how NRC might react to a point, he/she } \\
\text { needs to call and ask. }\end{array}$ & $\begin{array}{l}\text { Use NRC as a technical resource/sanity check and } \\
\text { not just for answering administrative-type } \\
\text { questions. Anytime the proposal preparer } \\
\text { questions how NRC might react to a point, he/she } \\
\text { needs to call NRC and ask. }\end{array}$ \\
\hline
\end{tabular}




\begin{tabular}{|c|c|}
\hline Issues & Recommendations \\
\hline $\begin{array}{l}\text { There is a risk in preparing the conversion } \\
\text { proposal while developing the fuel, because gaps, } \\
\text { tolerances, and such must be known, documented, } \\
\text { and understood. }\end{array}$ & $\begin{array}{l}\text { Complete the design before preparing the } \\
\text { conversion proposal. This will ensure the correct } \\
\text { design specs are included. The proposal can then } \\
\text { move forward with significantly minimized risk. } \\
\text { Transmit final drawings for fuel design to NRC to } \\
\text { support their review of the analyses. }\end{array}$ \\
\hline $\begin{array}{l}\text { Picking overly restrictive tolerances causes safety } \\
\text { limits to come down. Any future changes in } \\
\text { design means analyses have to be revisited and } \\
\text { sometimes revised. Over conservatism in } \\
\text { tolerances may make fabrication nearly } \\
\text { impossible. For example, the University of Florida } \\
\text { proposal asked for a } \pm 1 \text { mil tolerance across a } \\
\text { 26-in. element. This was rigorously discussed } \\
\text { internally at the University of Florida and ANL } \\
\text { (who conducted the analysis), but was not } \\
\text { discussed with the designers at INL who would } \\
\text { have resisted such a limited tolerance. }\end{array}$ & $\begin{array}{l}\text { Be less restrictive during the analysis so that we } \\
\text { are not so limited/restricted in the design. } \\
\text { The fabricator and the designer MUST collaborate } \\
\text { very closely at every phase of the process, almost } \\
\text { as if they were the same entity, so that nothing is } \\
\text { lost or overlooked. Better lines of communication } \\
\text { between those conducting the analysis and those } \\
\text { who are designing/fabricating the fuel are } \\
\text { essential. This will go a long way to resolving the } \\
\text { impacts of gap tolerances, design changes, and } \\
\text { such. } \\
\text { Involve ALL parties (e.g., analysis, design, } \\
\text { fabrication, and university) in ALL conversations } \\
\text { that will impact them directly or indirectly. Err on } \\
\text { the side of inclusion and let people opt out. }\end{array}$ \\
\hline
\end{tabular}

\subsubsection{Submittal of Proposal}

The average survey score was 3.20.

\begin{tabular}{|l|l|}
\hline \multicolumn{1}{|c|}{ Issue } & \multicolumn{1}{|c|}{ Recommendations } \\
\hline $\begin{array}{l}\text { Some confusion existed on whether the submittal } \\
\text { should be paper copy or electronic and how many } \\
\text { copies were needed. }\end{array}$ & $\begin{array}{l}\text { Call NRC when ready to submit the proposal and } \\
\text { ask the question. }\end{array}$ \\
\hline
\end{tabular}




\subsubsection{Requests for Additional Information}

The average survey score was 4.50 .

\begin{tabular}{|l|l|}
\hline \multicolumn{1}{|c|}{ Issues } & \multicolumn{1}{|c|}{ Recommendations } \\
\hline $\begin{array}{l}\text { After issuing the request for additional } \\
\text { information, NRC visited the university to discuss } \\
\text { their resolutions/dispositions to the questions. } \\
\text { This was extremely effective and worked to } \\
\text { expedite the question resolution process. }\end{array}$ & Continue this practice. \\
\hline $\begin{array}{l}\text { Before collaborative dialogue with NRC, the } \\
\text { university and ANL prepared a draft response to } \\
\text { the request for additional information so that } \\
\text { discussions during the visits/proposal review were } \\
\text { focused on the content of the response rather than } \\
\text { on understanding and clarifying the request for } \\
\text { additional information. This significantly } \\
\text { accelerated the process. }\end{array}$ & \\
\hline
\end{tabular}

\subsubsection{Final Review and Comment on Proposal}

The average survey score was 4.50 .

\begin{tabular}{|l|l|}
\hline \multicolumn{1}{|c|}{ Issues } & \multicolumn{1}{|c|}{ Recommendations } \\
\hline $\begin{array}{l}\text { This worked really well. Daily telecons to discuss } \\
\text { and resolve issues and the willingness of } \\
\text { participants to give and take to make it work was } \\
\text { invaluable. Great interaction, initiative, listening, } \\
\text { flexibility, and such. }\end{array}$ & Continue these practices. \\
\hline The common vision and mission were critical. & $\begin{array}{l}\text { Communicate these at the start of the project to all } \\
\text { concerned, and continue to refer to them } \\
\text { throughout the project. }\end{array}$ \\
\hline $\begin{array}{l}\text { Everyone had a great personal work ethic. } \\
\text { (his much as practicable, select team members with } \\
\text { established track records of success and } \\
\text { excellence. }\end{array}$ \\
\hline $\begin{array}{l}\text { We had a single person (Dana for INL and Benoit } \\
\text { for the University of Florida) that was solely } \\
\text { dedicated to the project (allowing that person to } \\
\text { stay in contact with all parties involved and to } \\
\text { identify and track issues). This was instrumental } \\
\text { to the success of the project. }\end{array}$ & $\begin{array}{l}\text { Identify a key point of contact for the program } \\
\text { and for the university to act in these roles. }\end{array}$ \\
\hline
\end{tabular}




\subsubsection{Conversion Order}

The average survey score was 3.50 .

\begin{tabular}{|l|l|}
\hline \multicolumn{1}{|c|}{ Issue } & \multicolumn{1}{|c|}{ Recommendation } \\
\hline $\begin{array}{l}\text { The NRC conversion order process went very } \\
\text { smoothly. NRC provided great support and quick } \\
\text { response to the proposal. This was highly } \\
\text { appreciated. }\end{array}$ & $\begin{array}{l}\text { Keep NRC informed; respect their role while } \\
\text { leveraging their experience and expertise. }\end{array}$ \\
\hline
\end{tabular}

NOTE: Many of these issues are discussed with regard to collaboration and clarification between designers and fabricators. Communication and misunderstandings appear to be the biggest issue. Designers and fabricators (and analysts) need to talk openly and often. Inclusive (i.e., all parties) communications is critical.

\subsection{Fuel and Hardware Development and Procurement}

\subsubsection{Fuel Specifications and Drawings}

The average survey score was 2.20 .

\begin{tabular}{|l|l|}
\hline \multicolumn{1}{|c|}{ Issues } & \multicolumn{1}{|c|}{ Recommendations } \\
\hline $\begin{array}{l}\text { Design decisions did not include all essential } \\
\text { members of the University of Florida team. }\end{array}$ & $\begin{array}{l}\text { Advise the university about how critical it is to } \\
\text { communicate and disseminate information among } \\
\text { its own team. }\end{array}$ \\
\hline $\begin{array}{l}\text { Many players do not have experience reading } \\
\text { drawings. }\end{array}$ & $\begin{array}{l}\text { Assistance from other departments or } \\
\text { organizations should be enlisted to assist the } \\
\text { university in areas where it is needed. }\end{array}$ \\
\hline $\begin{array}{l}\text { The INL prepared mockups of components, and } \\
\text { then when the University of Florida changed the } \\
\text { specifications based on an analysis, INL would } \\
\text { have to redo the mockup. This is expected; } \\
\text { however, open and frequent communication can } \\
\text { significantly minimize the impacts of those } \\
\text { occurrences and the rework involved. }\end{array}$ & $\begin{array}{l}\text { Anticipate an iterative process and advise those } \\
\text { involved that the process will be that way. The } \\
\text { design and specifications will change. We need to } \\
\text { be ready for it and not resist when such changes } \\
\text { come. }\end{array}$ \\
\hline $\begin{array}{l}\text { Absence of spacing and tolerance specifications } \\
\text { created confusion. }\end{array}$ & $\begin{array}{l}\text { Spacing requirements and tolerances need to be } \\
\text { clearly documented on the drawing. }\end{array}$ \\
\hline
\end{tabular}




\begin{tabular}{|l|l|}
\hline \multicolumn{1}{|c|}{ Issues } & \multicolumn{1}{|c|}{ Recommendations } \\
\hline $\begin{array}{l}\text { Assumptions with regard to design, fit, and } \\
\text { function proved invalid, requiring correction. }\end{array}$ & $\begin{array}{l}\text { Identify and document requirements such as } \\
\text { spacing, tolerances, fit-up, and such in a technical } \\
\text { and functional requirements document. }\end{array}$ \\
$\begin{array}{l}\text { Test all assumptions and VERIFY. Check the } \\
\text { details early on, perhaps as early as the initial } \\
\text { kickoff meeting. }\end{array}$ \\
$\begin{array}{l}\text { Perform mockups of designs to verify the designs } \\
\text { work. Include mockups as part of the critical path } \\
\text { so they are not forgotten. Verifying assumptions, } \\
\text { specs, designs, and such is especially critical } \\
\text { when continuity has been interrupted or extended } \\
\text { in the process. }\end{array}$ \\
\hline
\end{tabular}

\subsubsection{Fuel Fabrication Statement of Work and Procurement Documents}

The average survey score was 2.78 .

\begin{tabular}{|l|l|}
\hline \multicolumn{1}{|c|}{ Issues } & \multicolumn{1}{|c|}{ Recommendations } \\
\hline $\begin{array}{l}\text { Issues regarding fuel fabrication quickly arose } \\
\text { nearing the end of the process (e.g., questions on } \\
\text { fabrication process, quality assurance programs, } \\
\text { and channel spacing.) }\end{array}$ & $\begin{array}{l}\text { Advise the university to become familiar with the } \\
\text { fuel fabrication company's quality assurance } \\
\text { documents and process. }\end{array}$ \\
& $\begin{array}{l}\text { Involve the university in review and verification } \\
\text { of the fabricator's quality assurance program. }\end{array}$ \\
$\begin{array}{l}\text { Ensure the preliminary meeting between all } \\
\text { parties (e.g., university, analysts, designers, and } \\
\text { fabricators) occurs to discuss what each party will } \\
\text { get at each phase of the process. These same } \\
\text { parties should be included in status and issues } \\
\text { conversations throughout the process. }\end{array}$ \\
\hline $\begin{array}{l}\text { The INL/DOE relied on the licensee to maintain } \\
\text { the relationship with NRC and generally did not } \\
\text { get involved with that relationship. When changes } \\
\text { had to be made due to fabrication and analyses } \\
\text { issues, NRC was not informed in a timely manner. }\end{array}$ & $\begin{array}{l}\text { Advise and encourage the licensee to } \\
\text { communicate openly with NRC regarding changes } \\
\text { to fuel design and such. }\end{array}$ \\
$\begin{array}{l}\text { formicate all requirements for analyses and } \\
\text { submission of the proposal. }\end{array}$ \\
\hline
\end{tabular}




\begin{tabular}{|l|l|}
\hline \multicolumn{1}{|c|}{ Issues } & \multicolumn{1}{|c|}{ Recommendations } \\
\hline $\begin{array}{l}\text { The magnitude of support needed to accommodate } \\
\text { the changes in design and analyses was } \\
\text { overwhelming at times due to constraints in time. }\end{array}$ & $\begin{array}{l}\text { Planning and funding needs to anticipate making } \\
\text { resources available to handle the simultaneous } \\
\text { work. }\end{array}$ \\
\hline
\end{tabular}

\subsubsection{Fuel Inspection}

The average survey score was 4.00 .

\begin{tabular}{|l|l|}
\hline \multicolumn{1}{|c|}{ Issues } & \multicolumn{1}{|c|}{ Recommendations } \\
\hline $\begin{array}{l}\text { The blue books did not come with the fuel } \\
\text { (i.e., several weeks delayed). The inspections } \\
\text { were accomplished using advanced email or faxed } \\
\text { copies rather than the final books. }\end{array}$ & $\begin{array}{l}\text { Ensure the quality assurance documents are } \\
\text { provided up front. }\end{array}$ \\
$\begin{array}{l}\text { Could not verify individual plates because the } \\
\text { ACrial numbers are too small to read and the plates } \\
\text { were fastened into the elements. Having the blue } \\
\text { books would have helped alleviate this problem } \\
\text { because the books would have documented the } \\
\text { inspectors' conclusions that the plates were as } \\
\text { indicated on the drawings. }\end{array}$ & \\
\hline $\begin{array}{l}\text { Markings, labeling, and data were incomplete or the fuel. } \\
\text { scattered. }\end{array}$ & $\begin{array}{l}\text { Pull together all markings, labeling, and data } \\
\text { before inspections. }\end{array}$ \\
& $\begin{array}{l}\text { Conduct both source inspections and receipt } \\
\text { inspections. Advise the university to go to the } \\
\text { fabricator and inspect the fuel before shipping. }\end{array}$ \\
\hline
\end{tabular}

\subsubsection{Preparation of Facility for Fuel Receipt}

The average survey score was 3.60.

\begin{tabular}{|l|l|}
\hline \multicolumn{1}{|c|}{ Issues } & \multicolumn{1}{|c|}{ Recommendations } \\
\hline $\begin{array}{l}\text { The University of Florida was very restricted in } \\
\text { their receipt area. Knowing what size of trucks } \\
\text { could be accommodated was very helpful in } \\
\text { coordinating the receipt of fuel. Communication } \\
\text { of logistics between the university and the shipper } \\
\text { was critical to successful receipt of the fuels. }\end{array}$ & $\begin{array}{l}\text { Ensure the university and shipper communicate } \\
\text { with regard to logistics, restrictions, and such. }\end{array}$ \\
\hline
\end{tabular}




\begin{tabular}{|l|l|}
\hline \multicolumn{1}{|c|}{ Issues } & \multicolumn{1}{|c|}{ Recommendations } \\
\hline $\begin{array}{l}\text { Several different types of 6M drums were used at } \\
\text { the University of Florida. The hardware needed } \\
\text { for these drums was not communicated to the } \\
\text { university. }\end{array}$ & $\begin{array}{l}\text { Have shipper advice the university about the type } \\
\text { of 6M containers (e.g., drawings and opening } \\
\text { mechanisms) that will be arriving, so that the right } \\
\text { tools are onsite at the receipt location. }\end{array}$ \\
\hline
\end{tabular}

\subsubsection{Reassembly}

The average survey score was 3.33.

\begin{tabular}{|l|l|}
\hline \multicolumn{1}{|c|}{ Issue } & \multicolumn{1}{|c|}{ Recommendation } \\
\hline $\begin{array}{l}\text { Shipping assistance had to be provided to the } \\
\text { university to return the empty canisters because } \\
\text { the University of Florida was not familiar with the } \\
\text { process (e.g., paperwork). }\end{array}$ & $\begin{array}{l}\text { Make time early in the process to inform the } \\
\text { university about the requirements for return } \\
\text { shipment. }\end{array}$ \\
\hline
\end{tabular}

\subsection{Core Conversion}

\subsubsection{Fuel Removal}

The average survey score was 3.33.

\begin{tabular}{|l|l|}
\hline \multicolumn{1}{|c|}{ Issues } & \multicolumn{1}{|c|}{ Recommendations } \\
\hline $\begin{array}{l}\text { A 90-day shutdown period is required before } \\
\text { shipping the SNF. This timeframe needs to be } \\
\text { closely coordinated with the university to ensure } \\
\text { reactor needs are met and all implications of the } \\
\text { shutdown are considered. }\end{array}$ & $\begin{array}{l}\text { Make the university aware of the 90-day } \\
\text { requirement and advise them to consider the } \\
\text { implications of the schedule on reactor operations } \\
\text { and research. }\end{array}$ \\
\hline $\begin{array}{l}\text { Contractors assisting the university with activities } \\
\text { had unescorted access at the facility. Having } \\
\text { Secure Transportation Services qualified as } \\
\text { secondary operators at the reactor facility was } \\
\text { instrumental during operational activities. This } \\
\text { enabled them to move around and get things done } \\
\text { without having to be constantly escorted. }\end{array}$ & $\begin{array}{l}\text { Have contractors qualified as secondary operators } \\
\text { at the reactor facility, and provide them with } \\
\text { unescorted access. }\end{array}$ \\
\hline
\end{tabular}




\subsubsection{Refueling}

The average survey score was 3.50.

\begin{tabular}{|c|c|}
\hline Issues & Recommendations \\
\hline $\begin{array}{l}\text { Several activities (e.g., maintenance, } \\
\text { measurements, and disassembly) were required } \\
\text { that could have been carried out earlier. This } \\
\text { created a backlog as those activities became } \\
\text { critical path and created additional schedule } \\
\text { impacts. }\end{array}$ & $\begin{array}{l}\text { Consider these activities early on, identify those } \\
\text { that can be done earlier in support of conversion } \\
\text { and schedule them. Add additional } \\
\text { maintenance-type activities explicitly to the } \\
\text { schedule so that they can be considered in the } \\
\text { timing of the project. Activities that can be } \\
\text { performed before receiving new fuel and reactor } \\
\text { startup should be done as soon as possible, so as } \\
\text { to not interfere with critical activities. }\end{array}$ \\
\hline $\begin{array}{l}\text { There was some unfamiliarity with the } \\
\text { tools/equipment that needed to be resolved } \\
\text { real-time during refueling activities. During } \\
\text { loading, reactivity measurements were not } \\
\text { reconciling with the University of Florida's } \\
\text { calculations, causing uncertainty, questions, and } \\
\text { undue stress on the operation. Reactivity at } \\
\text { intermediate loading had not been calculated. }\end{array}$ & $\begin{array}{l}\text { Require the university to have a comprehensive } \\
\text { plan for refueling so they have a basis to reconcile } \\
\text { differences between the analysis and the core } \\
\text { measurements. This will be a formal } \\
\text { commissioning/startup plan that compares } \\
\text { calculated reactivity to measured values at } \\
\text { intermediate loading during the refueling process. } \\
\text { If possible, provide for onsite expertise to resolve } \\
\text { startup issues during refueling. In the absence of } \\
\text { onsite expertise, have a detailed plan and } \\
\text { procedures with lots of hold points. } \\
\text { Clarify explicit roles and responsibilities } \\
\text { (e.g., what-ifs and ways to respond). }\end{array}$ \\
\hline $\begin{array}{l}\text { The university encountered unanticipated } \\
\text { situations with regard to support equipment } \\
\text { operability or function. Numerous questions arose } \\
\text { as to how to respond to the arising issues. }\end{array}$ & $\begin{array}{l}\text { Check all needed equipment (maintained and } \\
\text { verified as operable) BEFORE you get to the } \\
\text { critical point where it is needed. Conduct routine } \\
\text { maintenance and pre-activity walk downs/ } \\
\text { inspection of all needed equipment. }\end{array}$ \\
\hline
\end{tabular}




\subsection{Spent Nuclear Fuel Shipment}

\subsubsection{Cask Determination}

The average survey score was 3.67.

\begin{tabular}{|l|l|}
\hline \multicolumn{1}{|c|}{ Issues } & \multicolumn{1}{|c|}{ Recommendations } \\
\hline $\begin{array}{l}\text { The university found the process for shipping } \\
\text { SNF/cores offsite overwhelming due to the } \\
\text { volume of orders and the regulations that applied. } \\
\text { Even though lots of guides and documents are } \\
\text { available, the pure volume of details and the } \\
\text { uniqueness of what needs to be done takes time } \\
\text { and coordination. }\end{array}$ & $\begin{array}{l}\text { Anticipate the likelihood of trepidation and the } \\
\text { sense of being overwhelmed. Be prepared to } \\
\text { provide encouragement, support, and guidance. }\end{array}$ \\
$\begin{array}{l}\text { Develop a generic guide and a workshop to } \\
\text { discuss shipping issues and put those who will be } \\
\text { responsible for shipping in contact with those who } \\
\text { have already done it. }\end{array}$ \\
$\begin{array}{l}\text { ACTION: Scott Declue will schedule a workshop } \\
\text { to discuss the related issues and draft a guide in } \\
\text { support of SNF shipping. } \\
\text { downs. This was especially valuable when done in } \\
\text { the preplanning stages. It opened the door for lots } \\
\text { of questions to be addressed early on. }\end{array}$ & $\begin{array}{l}\text { Continue to conduct these walk downs as a matter } \\
\text { of practice. }\end{array}$ \\
\hline
\end{tabular}

\subsubsection{Transportation Plan/Security Plan}

The average survey score was 3.0.

\begin{tabular}{|l|l|}
\hline \multicolumn{1}{|c|}{ Issue } & \multicolumn{1}{|c|}{ Recommendation } \\
\hline $\begin{array}{l}\text { Transportation and security plans are usually } \\
\text { developed in tandem so the appropriate } \\
\text { information can be conveyed, where allowed, with } \\
\text { the parties. On this University of Florida effort, } \\
\begin{array}{l}\text { we were under a security information lockdown } \\
\text { due to regulatory changes regarding safeguarded } \\
\text { information, and were not able to share everything } \\
\text { we needed to share. }\end{array}\end{array}$ & $\begin{array}{l}\text { The lockdown is over now, so this should not be a } \\
\text { problem in the future. } \\
\text { Need to begin the fingerprinting process early, } \\
\text { and make it appropriately and effectively } \\
\text { inclusive (include shippers). }\end{array}$ \\
\hline
\end{tabular}




\subsubsection{Route Assessment}

The average survey score was 3.2.

\begin{tabular}{|l|l|}
\hline \multicolumn{1}{|c|}{ Issue } & \multicolumn{1}{|c|}{ Recommendation } \\
\hline $\begin{array}{l}\text { The route assessment was performed late in the } \\
\text { process. }\end{array}$ & $\begin{array}{l}\text { Conduct the route assessment as early as possible. } \\
\text { Anything being shipped from a new location } \\
\text { needs to have the route assessed as early as } \\
\text { possible. }\end{array}$ \\
\hline
\end{tabular}

\subsubsection{Certification of University Quality Assurance Programs}

The average survey score was 3.0.

\begin{tabular}{|l|l|}
\hline \multicolumn{1}{|c|}{ Issues } & \multicolumn{1}{|c|}{ Recommendations } \\
\hline $\begin{array}{l}\text { Universities are, in large part, unfamiliar with } \\
\text { establishing a quality assurance program and } \\
\text { writing a quality assurance plan. }\end{array}$ & $\begin{array}{l}\text { Refer to other experienced universities, such as } \\
\text { MURR (Missouri), for guidance to the NRC } \\
\text { guidance. }\end{array}$ \\
\hline
\end{tabular}

\subsubsection{Facility Preparations for Spent Nuclear Fuel Activities}

The average survey score was 3.60 .

\begin{tabular}{|l|l|}
\hline \multicolumn{1}{|c|}{ Issue } & \multicolumn{1}{c|}{ Recommendation } \\
\hline $\begin{array}{l}\text { Proactive, early involvement in preparing } \\
\text { facilities for SNF activities is critical to success }\end{array}$ & $\begin{array}{l}\text { Encourage and facilitate the inclusion of those } \\
\text { involved in SNF activities in early discussion and } \\
\text { preparations. }\end{array}$ \\
\hline
\end{tabular}




\subsubsection{Support Equipment/Tools for Spent Nuclear Fuel Activities}

The average survey score was 3.60.

\begin{tabular}{|l|l|}
\hline \multicolumn{1}{|c|}{ Issues } & \multicolumn{1}{|c|}{ Recommendations } \\
\hline $\begin{array}{l}\text { A lid was built in accordance with the drawing; } \\
\text { however, no one realized that the drawing was } \\
\text { looking up at the lid. Subsequently, the lid was } \\
\text { inverted. The error was caught during an } \\
\text { unplanned dry run that was conducted during a } \\
\text { project delay; therefore, no time was lost. Had } \\
\text { there not been a delay, the project would have } \\
\text { been hard pressed to correct the error. }\end{array}$ & $\begin{array}{l}\text { (1) Pay closer attention to detail, and (2) conduct } \\
\text { dry runs of newly designed equipment. }\end{array}$ \\
\hline Each facility has its own equipment needs. & $\begin{array}{l}\text { Identify specific equipment needs as early as } \\
\text { possible. }\end{array}$ \\
\hline
\end{tabular}

\subsubsection{Appendix A Preparation}

The average survey score was 2.5 .

\begin{tabular}{|c|c|}
\hline Issues & Recommendations \\
\hline $\begin{array}{l}\text { Identification numbers on the fuel did not match } \\
\text { the identification numbers listed in Appendix A. }\end{array}$ & $\begin{array}{l}\text { Convey the importance of fuel element } \\
\text { identification numbers to the shipper. If a } \\
\text { discrepancy is found in the numbers, it should be } \\
\text { documented and faxed to the field office } \\
\text { immediately for response and resolution. }\end{array}$ \\
\hline $\begin{array}{l}\text { The university was not experienced nor prepared } \\
\text { for the requirements of Appendix A submission. } \\
\text { The preparation can be cumbersome, complex, } \\
\text { and confusing. }\end{array}$ & $\begin{array}{l}\text { Advise licensees of the requirements of the } \\
\text { Appendix A submittal. } \\
\text { Prepare a simplified guidance document (similar } \\
\text { to a 1040A tax form) to show licensees how to } \\
\text { prepare Appendix A. } \\
\text { ACTION: Scott Declue will schedule a workshop } \\
\text { to review Appendix A requirements and come up } \\
\text { with a plan for providing the needed guidance. }\end{array}$ \\
\hline
\end{tabular}




\subsubsection{Shipping Documentation}

The average survey score was 3.0.

\begin{tabular}{|l|l|}
\hline \multicolumn{1}{|c|}{ Issues } & \multicolumn{1}{|c|}{ Recommendations } \\
\hline $\begin{array}{l}\text { Required labels on the cask were torn off during } \\
\text { transport due to harsh weather conditions. }\end{array}$ & $\begin{array}{l}\text { Harsh weather conditions need to be considered } \\
\text { when affixing labels. }\end{array}$ \\
\hline $\begin{array}{l}\text { Photos were taken of the BMI cask before } \\
\text { shipping, showing the labels were in place before } \\
\text { leaving the university. }\end{array}$ & $\begin{array}{l}\text { Continue this practice of taking photos. They can } \\
\text { be essential in providing information as a } \\
\text { verification mechanism to regulating entities, } \\
\text { especially when things change during transit. }\end{array}$ \\
\hline
\end{tabular}

\subsubsection{Cask Loading}

The average survey score was 3.67.

\begin{tabular}{|l|l|}
\hline \multicolumn{1}{|c|}{ Issue } & \multicolumn{1}{|c|}{ Recommendations } \\
\hline The lid for cask loading required rework. & $\begin{array}{l}\text { Performing a "dry-run" of loading activities is } \\
\text { essential to identifying problems with procedures, } \\
\text { equipment, and such. }\end{array}$ \\
\hline
\end{tabular}

\subsubsection{Receipt Facility Preparation}

The average survey score was 3.33 .

\begin{tabular}{|l|l|}
\hline \multicolumn{1}{|c|}{ Issue } & \multicolumn{1}{|c|}{ Recommendations } \\
\hline $\begin{array}{l}\text { The University of Florida needed to have SNF } \\
\text { shipped offsite in an extremely compressed } \\
\text { schedule due to many factors (e.g., availability } \\
\text { and scheduling of BMI casks and security issues } \\
\text { of holding HEU in storage at the university). }\end{array}$ & $\begin{array}{l}\text { Advise university of the need for comprehensive } \\
\text { planning, attention to detail, and anticipation of all } \\
\text { relevant factors in preparing, scheduling, and } \\
\text { shipping SNF. } \\
\text { impacted transport. }\end{array}$ \\
$\begin{array}{l}\text { Have flexibility to relax the schedule if safety } \\
\text { issues are a concern. }\end{array}$ \\
\hline
\end{tabular}




\subsection{Other Issues}

\subsubsection{Safeguarded Information}

The average survey score was 3.0.

\begin{tabular}{|l|l|}
\hline \multicolumn{1}{|c|}{ Issues } & \multicolumn{1}{|c|}{ Recommendations } \\
\hline $\begin{array}{l}\text { The safeguards information issues have been } \\
\text { resolved at NRC. }\end{array}$ & $\begin{array}{l}\text { Submit fingerprints and other such information as } \\
\text { soon as possible. }\end{array}$ \\
\hline
\end{tabular}

\section{ROUND ROBIN}

In concluding the discussion of the lessons learned, all participants were invited to reiterate, summarize, or offer any other lessons learned. The following list provides their final thoughts:

- $\quad$ There were lots of challenges on this project, but the team pulled together to meet those challenges and complete the project on schedule. Well done.

- $\quad$ The key to success was that everyone had the same goal and worked together to accomplish it.

- $\quad$ Next time we decide to use cones on the fuel plates, we need to taper them and not use hard edges. They do not go into the box very easily when they have hard edges.

- If we decide to have a workshop (e.g., initial orientation to the work and expectations), let us consider a single, comprehensive document and guidance that will address all of these issues with appropriate templates. It would be ineffective to pull all these people together in separate meetings to discuss each issue separately. A single guidance document and workshop would be the most efficient way to address it.

- $\quad$ Everyone in the project was working at or near capacity; therefore, the stress level was very high. It is great to work with people who can perform under such circumstances and know their limits so the work is (was) appropriately managed.

- It takes some time after refueling for the university to get the reactor up and running and to get operations back to normal. During this time, new operating procedures have to be written and operators have to be trained to the new procedures. The message here is that you will not start conversion on Monday and be back to full operation the next Monday. The transition and startup time after refueling needs to be planned for and coordinated. Additionally, the universities must prepare and have knowledge of reactor physics with appropriate onsite expertise. Certain parameters are needed to run tests in the reactor, and many of the operators do not have the reactor physics knowledge to do it. Depth of knowledge is the issue.

- Need to add operator training to the commissioning/startup plan that is discussed above. This is where the analysis information is conveyed to the operator. New operating procedures also need to be written, trained to, and implemented. 
- $\quad$ Steps to success - communicate, plan, verify, and communicate. We need to involve future licensees in the next lessons learned meeting so they can have the information up front.

- Do not submit the conversion proposal and application until the information is full and complete.

- How issues are handled when they arise is a good indicator of the strength of the team. This was a great team.

\section{ACTIONS}

Scott will take the lead to establish a workshop to address activities needed for SNF shipping.

BWXT will check to see why the blue books were not sent with the fuel.

\section{CONCLUSION}

This lessons learned process has allowed us to capture gaps, opportunities, and good practices, drawing from the project team's experiences. The process is inclusive and offers an opportunity for every entity that "touched" the project to share from its experience. These lessons will be used to raise the standard of excellence, effectiveness, and efficiency in all future conversion projects. Despite making improvements to successive projects by addressing the lessons we have learned on this project, conducting a lessons learned activity will be vital to each conversion project as technologies, regulations, and other aspects of the environment change and influence success. It is recognized we cannot become complacent, nor adopt a mindset that the process has been "perfected." 